\title{
Sex Education - Why Bother? The Contribution of a Sex Education Course in a Multicultural College for Student- Teachers
}

\author{
Judith Lapidot Berman \& Esther Firstater \\ Gordon College of Education, Haifa, Israel \\ Email: judithlapidotberman@gmail.com
}

\begin{abstract}
This paper describes the results of a quantitative research study, pre and post design, conducted in a multicultural teachers' college in Israel, with the purpose of investigating differences between student-teachers who completed a "Human Sexuality" course and a control group, which did not. Three variables were examined: knowledge, attitudes concerning different aspects of human sexuality and self-efficacy to deal with sex education. The main findings of the research indicate a significant increase in knowledge and self-efficacy of the students, both Jews and Arabs, in the research group, but not in the control group. Attitudes were more progressive in the research group after the course, but did not change in the control group.
\end{abstract}

Keywords: Sex education, human sexuality, attitude change, student-teachers, multicultural education.

\section{Introduction}

The Israeli society is multicultural in various aspects. The Jewish-Arab ethnic division is the most significant one, and is reflected in different attitudes towards various issues, including human sexuality. In recent years, the Israeli media has flooded the public with reports on ugly expressions of human sexuality in both ethnic groups. Among them: sexual violence and injury towards and perpetrated by children, youth and adults; sexual harassment at work and in institutions of higher education; indecent assault and rape, including crimes by eminent public officials; children or adolescents perpetrating sexual offences alone or in groups; children and youth sending each other sexually explicit cell-phone messages, photos and short video films ("sexting").

Harpaz [1] argues that young people's violent sexual behavior is due, in part, to the failure of parents and the educational system to fulfil their roles as educators, particularly with regard to sex education. Mass media has filled this educational void with accessible pornography, presenting distorted models of sexual relations based on sex instead of love and reciprocal commitment. At the same time, schools have failed to provide the protective environment and climate needed by students who, either voluntarily or under coercion, have exposed their homosexual tendencies, and who are often subsequently forced to cope with public prejudice and stereotypes [2].

These situations require the adult intervention of parents and educators [1,3] and highlight in particular the school's role in promoting healthy sexuality through substantive discussion on the relation between human sexuality and relationships. A strong foundation of knowledge, provided during teacher training, is a fundamental condition to provide teachers with the necessary skills to deal effectively with the subject of sex education and to shape positive attitudes towards different aspects of human sexuality.

This research examines the significant advantages of teaching a "Human Sexuality" course within the framework of a multicultural teacher-training college in terms of enhancing three variables: knowledge, attitudes towards human sexuality and self-efficacy to deal with sex education. These variables were examined in relation to ethnic and religious aspects, which are very significant in the Israeli society. 


\section{Theoretical Background}

\subsection{The Association between Knowledge and Attitudes towards Sexuality}

Knowledge is one of the variables that shape human sexuality. Research indicates that knowledge is essential for the formation of progressive attitudes towards sexuality among young people [4,5]. A lack of information or incorrect information leads to mistaken thinking schemes concerning sex and sexuality, which in turn can lead to anxiety, guilt, unrealistic expectations or fear of failure. The most prevalent forms of misinformation are the myths that surround the issue of sex, based on mistaken unscientific information. These myths negatively influence expectations from sex and can cause defective sexual functioning [6].

Noland, Bass, Keathley \& Miller [7] showed that, college students who completed courses dealing with human sexuality demonstrated more knowledge concerning sex than students who did not attend those courses. Their research also indicated that graduates of those courses held fewer negative attitudes concerning homosexual tendencies. A positive change in attitudes towards homosexuality was also found in a study of social work students who acquired knowledge in a course on homosexuality [8]. Those who did not complete the course did not alter their opinions. Another study [9], investigating students' attitudes, perceptions and beliefs in a Chinese university, yielded similar findings: a positive correlation was found between students' knowledge of terminology concerning homosexuality and attitudes towards it. A significant alteration of attitudes towards homosexuality also correlated with the age at which participants were first exposed to this concept. It seems that exposing children at an early age to the knowledge that such a sexual orientation exists, may help shape more tolerant attitudes towards homosexuality (ibid).

Familiarity with members of the LGBT community (Lesbian, Gay, Bisexual and Transgender), provides direct knowledge of these sexual orientations. Sakalli-Ugurlu [10] found a positive correlation between personal acquaintance with homosexuals and less prejudice towards them. Similarly, Riggs, Webber \& Fell [11] found that psychology students who had prior acquaintance with transsexuals displayed more positive attitudes towards them than did their colleagues. Perez-Testor et al. [12] investigated covert and overt attitudes towards homosexuality among teachers in Barcelona. Their covert attitudes towards transsexuals were more negative than the overt attitudes, and resembled the attitudes of other sectors of society. The researchers also reported a small discrepancy between declared personal values ("how I should behave") and declared behavior ("how I am likely to behave"). These findings reinforce findings by Riggs et al. [11], that prior acquaintance with homosexuals and lesbians reduces homophobia and prejudices.

\subsection{The Association between Ethnic Background, Level of Religiosity and Attitudes towards Sexuality}

Differences in opinions concerning homosexuality, traditional gender roles, casual sexual relations, and extramarital sexual relations were investigated in people from various religious and ethnic backgrounds. In Israel, Shilo [13] found differences between the attitudes of religious and secular students towards homosexuality. Secular students held attitudes that are more progressive. Similarly, a study of Turkish students showed that a strong affinity with the religion of Islam and frequent participation in the act of prayer constituted strong predictors for more negative attitudes towards homosexuality [14].

A similar correlation was found, moreover, between religiosity and negative, overt and covert attitudes to homosexuality among teachers in Spain [12,15]. A possible explanation for these findings is the existence of an explicit prohibition against homosexuality in the three monotheistic religions: Judaism, Christianity and Islam [16].

There also seems to be a basis for a connection between ethnic and cultural identity and attitudes toward sexuality. For example, differences were found between attitudes of black and white students towards homosexuality: black students held neutral attitudes, while white students had slightly more positive attitudes [17]. Ahrold \& Meston [18] investigated attitudes towards sex among Euro-American, Asian, and Hispanic students in America. Asian students held more conservative attitudes than Euro- 
American and Hispanic students. However, a higher level of acculturation among Hispanic and Asian students (second-generation immigrants) predicted attitudes similar to those of Euro-Americans.

The above-mentioned study by Sumer [14] also examined the attitudes of Turkish students towards masturbation. As with attitudes towards homosexuality, more progressive attitudes towards masturbation were found among students who declared a lower level of religiosity and who participated only infrequently in religious ceremonies.

\subsection{Sex Education}

Sex education contributes to the formation of attitudes towards sexuality, especially among children and adolescents. Effective sex education can encourage young people to reduce dangerous sexual behavior, including behavior associated with the risk of sexually transmitted diseases, unwanted pregnancies and harmful sexual activities $[19,20]$.

Harpaz [21] described two different perceptions regarding sex education in schools: the first argues that schools are not prepared and it is not their job to be prepared to deal with sex education, since the main role of a school is to impart information and skills only in particular areas of knowledge. The second perception sees the school as obliged to deal with this subject, since ignoring and denying sexuality cannot prevent its destructive aspects. Dr. David Green, a clinical psychologist, told Harpaz [1] that the curriculum in Israel emphasizes teaching only the core subjects over providing a broad-based education, particularly with regard to the subject of sex education.

Since it is loaded with values and moral questions, sex education stimulates disagreement between policy makers, educators and parents concerning its character, contents, and status [22]. Thus, for example, some states in the USA consider it a responsibility of the school system to provide sex education, while other states direct their schools only insofar as to educate children to avoid premarital sex. Some states have adopted an intermediate approach, requiring schools to educate for avoidance of sexual relations, but simultaneously requiring that students be given information on contraceptives and prevention of sexually transmitted diseases. The disagreements relate to the goals of sex education, ways to implement it, and ways for teachers to cope with ethical-moral issues. Most western states agree that sex education should be included in the curriculum. Such education, moreover, should relate to a wide variety of subjects, from anatomy and physiology of the reproductive organs, to knowledge concerning gender identity, the variety of sexual orientations, prevention of sexually transmitted diseases, contraception, and stereotypes in mass media [1]. It seems that structured sex education contributes significantly to the development of healthy sexual behavior and attitudes [6]. A study of attitudes towards homosexuals and lesbians among social work students in the USA found, for example, that an experiential exercise or workshop reduced prejudices [23].

Sex education is ineffective, however, if teachers do not feel comfortable with the contents and the teaching methods, or if their values clash with the subject matter [24]. In general, a strong foundation of knowledge of the subject matter reinforces the teachers' sense of competence to teach it [25, 26]. Research studying student teachers' sense of self-efficacy in teaching different subjects related to sex education found that the student teachers felt confident to deal with issues such as positive communication with the family and physical and social changes during adolescence. However, they were less comfortable teaching subjects such as masturbation, demonstrating use of condoms and relating to sexual orientations. These findings indicate that student teachers should receive health and sex education, in order to prepare them to deal with sex education in schools [27].

Teachers who received proper training in sex education succeeded in generating significant change in pupils' learning processes [28]. In contrast, a study in Uganda [29] found that teachers who lacked sufficient knowledge perpetuated traditional values which limited access to information and to sexual health services, even though this was not their intention. A study in Turkey examining student teachers' attitudes following their participation in a sex education course found that their attitudes towards sexuality were more positive and tolerant, but not towards homosexuality [30].

Sex education programs should take into consideration the traditions and characteristics of teachers and pupils, and involve parents in these programs [6, 31]. A study in Israel [32] found that Arab teachers support setting boundaries on the sexual behavior of their pupils, while Jewish teachers support giving students the freedom to make their own decisions, after supplying them with relevant information. 
It was also found that Arab teachers are more concerned that teaching their pupils about contraception might encourage them to engage in sexual relations.

In Israel, sex education is under the jurisdiction of the Unit for Education on Sexuality, Coupledom and Family Life in the Ministry of Education's Psychological-Counselling Service. Sex education is studied in schools as one of various subjects in the "Life Skills" program [33]. Teachers teach the subject under the guidance of school counsellors, and sometimes the counsellors themselves teach the subject. Although the "Life Skills" program is compulsory, it is only taught in $60 \%-70 \%$ of the schools, and even in these schools it does not always include human sexuality contents (ibid.). According to Zvieli-Efrat [2], although several sex education programs have been developed in Israel, their implementation is not optimal due to a shortage of professionals qualified to teach the subject or insufficient allocation of time and resources.

Research has shown that sex education is an important factor in shaping attitudes concerning sexuality. It has also highlighted the significance of knowledge as a condition for a sense of capability to teach.

The purpose of this study was to assess the contribution of a human sexuality course to Jewish and Arab student teachers, regarding their knowledge, attitudes toward sexuality and sex education and selfefficacy to teach it.

\section{$3 \quad$ Method}

\subsection{Hypotheses}

1. Students participating in the human sexuality course have better knowledge, more accepting attitudes toward sexuality and sex education and a higher self-efficacy regarding teaching about sexuality, than students who did not participate in the course.

2. Ethnic background and the level of religiosity will be related with differences in knowledge, differences in attitudes toward sexuality and sex education, and differences in self-efficacy regarding teaching about sexuality.

\subsection{Participants}

Participants were college students from seven classes in a teacher's college located in Israel. Three classes participated in the "Human Sexuality" course (the experimental group) and four did not (the control group). There were 170 questionnaires collected at the beginning of the academic semester and 134 at its end, resulting in a total of 304 questionnaires: 75 pre-study experimental group questionnaires (25\%), 95 pre-study control group questionnaires (31\%), 62 post-study experimental group questionnaires (20\%) and 72 post-study control group questionnaires (24\%).

The following demographic description is based on the 170 pre-study questionnaires, in 143 of which demographic information was provided (84\%). Most participants were first year students $(\mathrm{n}=109,76 \%)$, and most were females $(\mathrm{n}=135,94 \%)$, ranging in age from 18 to 50 years old, with a mean of 26.09 years $(\mathrm{SD}=6.49$ years, median $=24$ years $)$. Most were single $(\mathrm{n}=89,62 \%)$, and others were married $(\mathrm{n}$ $=48,34 \%)$ or divorced $(\mathrm{n}=6,4 \%)$. Thirty-seven students $(26 \%)$ had children. Most students were Jewish $(\mathrm{n}=99,69 \%)$ and others were Arab $(\mathrm{n}=44,31 \%)$. About half were secular $(\mathrm{n}=69,55 \%)$, and others were traditional $(\mathrm{n}=51,40 \%)$ or religious $(\mathrm{n}=6,5 \%)$. Only eight students $(6 \%)$ had taken a sexuality course in the past. No demographic differences were found between the experimental and control groups.

\subsection{Research Tools}

Knoweldge: Questionnaire was based on Kite \& Deaux [34]. Items of the original questionnaire were adapted or replaced to fit the contents of the "Human Sexuality" course. Fourteen statements were used, concerning masturbation, contraception, anatomy and physiology of the human reproductive organs and female circumcision. For example, "Masturbation harms males' fertility." The respondents were asked to 
mark each statement as "correct" (coded 1) or "incorrect" (coded 0). Internal consistency was a =0.70. The total score was composed from the sum of the items and converted to a 0-100 scale.

Attitudes toward sexuality: Questionnaire was based on Kite \& Deaux [34]. Items of the original questionnaire were adapted or replaced to fit the contents of the "Human Sexuality" course. Twenty-one items were used regarding: sexual relations, menstruation, unisexual tendencies, masturbation. For example: "Homosexuality is a sexual deviation." Items were rated on a Likert scale of 1-4: where $1=$ do not agree at all, and $4=$ strongly agree. Internal consistency was $\alpha=0.85$. The overall score was the average of all ratings, with a higher score indicating more accepting attitudes.

Self-efficacy for sex education: Five items were used regarding the respondents' self-efficacy to deal with sex education concerning children and adolescents. For example: "I feel confident that I am capable to deliver lessons on sex education". Items were rated on a Likert scale of 1-4: where $1=$ do not agree at all, and $4=$ strongly agree. Internal consistency was $\alpha=0.68$. The overall score was the average of all ratings, with a higher score indicating higher self-efficacy.

Students were also asked to complete four sentences dealing with self-efficacy for sex education ("If asked to teach a lesson in sexual education I....") and attitudes ("If my son told me he was a homosexual, I..."; "If I found that a friend was having oral sex I...."; "If I found that my 4 year old son was masturbating, I...."). Students' responses were coded as positive (1) or negative (0) by two expert judges. Good Kappa values were received for inter rater agreement: 0.83, 0.87, 0.88, $0.87(\mathrm{p}<.001$, listed in the order of the examples above). The total score for each sentence was composed of the mean of the two judges.

Background data: Included gender, family status, ethnic affiliation (Jewish or Arab), level of religiosity (secular, traditional or religious), age, year of studies in the college, prior enrolment in an academic course on issues of human sexuality.

\subsection{Research Procedure}

Permission was obtained from the college research committee to administer the research questionnaires to student teachers. The research participants, both in the experimental and control groups, completed the questionnaires in the first lesson at the beginning of the semester (hereinafter: "pre"), and at the end, in the last lesson of the semester (hereinafter: "post"). The questionnaires were administered to the students by the researchers. In order to improve the objectivity of the responses, respondents were told that the researchers conducting this research were from another academic institute. The questionnaires were completed anonymously; it took approximately 25 minutes for the student teachers to complete them.

\subsection{Data Processing}

The research hypotheses were examined with a between-subjects two-directional multivariate analysis of variance (MANOVA), examining differences in the research variables by group and time point. Differences in the research variables by group, time point, and ethnic affiliation or religiosity were examined with a three-directional MANOVA. The extent of difference in sentence completion was analysed with the non-parametric Mann-Whitney U test.

\section{$4 \quad$ Findings}

\subsection{Descriptive Statistics}

Before the research hypotheses were tested, descriptive statistics were calculated, regarding the main variables at the beginning of the research ("pre") (Table 1).

Table 1. Descriptive statistics

\begin{tabular}{l|c|c|c|c}
\hline Variable & $\begin{array}{c}\text { Experiment } \\
\mathrm{M}\end{array}$ & $\begin{array}{c}\text { Control } \\
\mathrm{M} \\
\mathrm{SD}\end{array}$ & $\begin{array}{c}\text { Experiment } \\
\text { range }\end{array}$ & $\begin{array}{c}\text { Control } \\
\text { range }\end{array}$ \\
\hline
\end{tabular}




\begin{tabular}{l|c|c|c|c}
\hline Knowledge & $\begin{array}{c}56.59 \\
(22.01)\end{array}$ & $\begin{array}{c}61.03 \\
(19.59)\end{array}$ & $8-100$ & $8-100$ \\
\hline Self-efficacy & $\begin{array}{c}2.80 \\
(0.77)\end{array}$ & $\begin{array}{c}2.76 \\
(0.66)\end{array}$ & $1-4$ & $1-4$ \\
\hline Attitudes & $\begin{array}{c}3.04 \\
(0.61)\end{array}$ & $\begin{array}{c}3.11 \\
(0.51)\end{array}$ & $1-4$ & $1-4$ \\
\hline
\end{tabular}

Non-significant differences in the research variables were found between the experimental and control groups $(\mathrm{F}(3,162)=0.42, \mathrm{p}=.742, \eta 2=.008)$. In other words, the two groups were not distinguished one from the other before the research, with regard to the three variables: knowledge, self-efficacy and attitudes.

Positive correlations were found between the following research variables (beyond time): between knowledge and self-efficacy $(\mathrm{r}=.38, \mathrm{p}<.001)$; between knowledge and attitudes $(\mathrm{r}=.57, \mathrm{p}<.001)$; and between self-efficacy and attitudes $(\mathrm{r}=.44, \mathrm{p}<.001)$. The higher the knowledge, the greater the selfefficacy and the more progressive the attitudes will be.

Age was positively related with the study variables (knowledge $\mathrm{r}=.21$, self-efficacy $\mathrm{r}=.24$, and attitudes $\mathrm{r}=.19, \mathrm{p}<.001$ ), showing that older participants tended to have greater knowledge, higher self-efficacy and more progressive attitudes, although the correlations are weak. Yet, no correlation was found between family status or year of studies and the research variables.

The findings show that ethnic affiliation (Jewish or Arab) and the level of religiosity correlated with the three variables (see Tables 3 and 4 ).

\subsection{Differences between "Pre" versus "Post", Regarding the Three Research Variables}

In order to test research hypotheses, pre-post differences in knowledge, self-efficacy and attitudes by group (experimental/control) were examined, using multivariate analysis of variance (MANOVA). Results appear in Table 2.

The analysis was found significant for group $(\mathrm{F}(3,288)=4.32, \mathrm{p}=.005, \eta 2=.043)$, for time $(\mathrm{F}(3$, $288)=7.52, \mathrm{p}<.001, \eta 2=.073)$, and for the interaction of group by time $(\mathrm{F}(3,288)=6.00, \mathrm{p}<.001$, $\eta 2=.059)$

Results in Table 2 reveal that all three interactions were significant. Post hoc analyses showed that while all time differences in the experimental group were significant, all time differences in the control group were non-significant. Knowledge in the experimental group: $\mathrm{F}(1,290)=32.46, \mathrm{p}<.001, \eta 2=.101$, knowledge in the control group: $\mathrm{F}(1,290)=0.11, \mathrm{p}=.742, \eta 2=.001$, self-efficacy in the experimental group: $\mathrm{F}(1,290)=16.87, \mathrm{p}<.001, \eta 2=.055$, self-efficacy in the control group: $\mathrm{F}(1,290)=0.11, \mathrm{p}$ $=.749, \eta 2=.001$, attitudes in the experimental group: $\mathrm{F}(1,290)=11.09, \mathrm{p}<.001, \eta 2=.037$, attitudes in the control group: $\mathrm{F}(1,290)=0.18, \mathrm{p}=.675, \eta 2=.001$.

Table 2. Means, standard deviations and F values for time and group differences in knowledge, self-efficacy and attitudes $(\mathrm{N}=294)$

\begin{tabular}{c|c|c|c|c|c|c|c}
\hline & \multicolumn{2}{|c|}{ Experiment } & \multicolumn{2}{|c|}{ Control } & Fgroup & Ftime & Fgroup x time \\
& Pre & Post & Pre & Post & $(1,290)$ & $(1,290)$ & $\begin{array}{c}(1,290) \\
(\eta 2)\end{array}$ \\
& $\mathrm{M}$ & $\mathrm{M}$ & $\mathrm{M}$ & $\mathrm{M}$ & $(\eta 2)$ & $(\eta 2)$ & \\
& $(\mathrm{SD})$ & $(\mathrm{SD})$ & $(\mathrm{SD})$ & $(\mathrm{SD})$ & & & \\
& $(\mathrm{n}=74)$ & $(\mathrm{n}=62)$ & $(\mathrm{n}=89)$ & $(\mathrm{n}=69)$ & & & \\
\hline \multirow{2}{*}{ Knowledge } & 56.59 & 76.92 & 61.03 & 62.13 & $4.49^{*}$ & $19.30^{* * *}$ & $\begin{array}{c}15.56^{* * *} \\
\end{array}$ \\
& $(22.01)$ & $(17.99)$ & $(19.59)$ & $(22.92)$ & $(.015)$ & $(.062)$ & $(.051)$ \\
\hline \multirow{2}{*}{ Self -efficacy } & 2.80 & 3.26 & 2.76 & 2.79 & $10.91^{* * *}$ & $10.39^{* * *}$ & $7.77^{* *}$ \\
& $(0.77)$ & $(0.53)$ & $(0.66)$ & $(0.61)$ & $(.036)$ & $(.035)$ & $(.026)$ \\
\hline \multirow{2}{*}{ Attitudes } & 3.04 & 3.36 & 3.11 & 3.15 & 1.21 & $7.42^{* *}$ & $4.62^{*}$ \\
& $(0.61)$ & $(0.57)$ & $(0.51)$ & $(0.54)$ & $(.004)$ & $(.025)$ & $(.016)$ \\
\hline
\end{tabular}

${ }^{*} \mathrm{p}<.05, * * \mathrm{p}<.01, * * * \mathrm{p}<.001$ 
The level of self-efficacy increased in the experimental group from a pre average of 2.8 to a post average of 3.3 (on a Likert scale of 1-4), while the average remained at 2.8 in the control group. The attitudes declared by the students in the experimental group were already quite progressive at the pre stage (average 3.0), and rose slightly at the post stage (average 3.4). The average in the control group was and remained at 3.1 .

\subsection{Differences in the Three Research Variables by Ethnic Affiliation}

Differences were examined for the research variables in relation to ethnic affiliation. Table 3 presents means and SD for the research variables, by group (experimental/control), time (pre/post), and ethnic affiliation (Jewish/Arab). It was found that Jewish students had greater knowledge than Arab students at the beginning of the study ("pre") $(\mathrm{F}(1,137)=30.16, \mathrm{p}<.001, \eta 2=.180)$, higher self-efficacy $(\mathrm{F}(1$, $137)=7.45, \mathrm{p}=.007, \eta 2=.052)$ and more progressive attitudes $(\mathrm{F}(1,137)=82.66, \mathrm{p}<.001, \eta 2$ $=.376)$.

Table 3. Means and standard deviations of the study variables by group, time and ethnicity $(\mathrm{N}=273)$

\begin{tabular}{|c|c|c|c|c|c|c|c|c|}
\hline & \multicolumn{4}{|c|}{ Experiment } & \multicolumn{4}{|c|}{ Control } \\
\hline & \multicolumn{2}{|c|}{$\begin{array}{c}\text { Pre } \\
\text { M } \\
(\mathrm{SD}) \\
(\mathrm{n}=71) \\
\end{array}$} & \multicolumn{2}{|c|}{$\begin{array}{c}\text { Post } \\
\mathrm{M} \\
(\mathrm{SD}) \\
(\mathrm{n}=62)\end{array}$} & \multicolumn{2}{|c|}{$\begin{array}{c}\text { Pre } \\
\mathrm{M} \\
(\mathrm{SD}) \\
(\mathrm{n}=71)\end{array}$} & \multicolumn{2}{|c|}{$\begin{array}{c}\text { Post } \\
\mathrm{M} \\
(\mathrm{SD}) \\
(\mathrm{n}=69)\end{array}$} \\
\hline & $\begin{array}{l}\text { Jewish } \\
(\mathrm{n}=45)\end{array}$ & $\begin{array}{c}\text { Arab } \\
(n=26)\end{array}$ & $\begin{array}{l}\text { Jewish } \\
(\mathrm{n}=45)\end{array}$ & $\begin{array}{c}\text { Arab } \\
(\mathrm{n}=17) \\
\end{array}$ & $\begin{array}{l}\text { Jewish } \\
(\mathrm{n}=53) \\
\end{array}$ & $\begin{array}{c}\text { Arab } \\
(\mathrm{n}=18) \\
\end{array}$ & $\begin{array}{l}\text { Jewish } \\
(\mathrm{n}=57) \\
\end{array}$ & $\begin{array}{c}\text { Arab } \\
(\mathrm{n}=12) \\
\end{array}$ \\
\hline Knowledge & $\begin{array}{c}66.77 \\
(16.15) \\
\end{array}$ & $\begin{array}{c}40.38 \\
(21.27) \\
\end{array}$ & $\begin{array}{c}82.14 \\
(15.05) \\
\end{array}$ & $\begin{array}{r}63.10 \\
(18.21) \\
\end{array}$ & $\begin{array}{c}63.52 \\
(18.02) \\
\end{array}$ & $\begin{array}{r}52.75 \\
(23.55) \\
\end{array}$ & $\begin{array}{r}61.69 \\
(24.27) \\
\end{array}$ & $\begin{array}{c}59.47 \\
(18.13) \\
\end{array}$ \\
\hline Self-efficacy & $\begin{array}{r}2.97 \\
(0.65) \\
\end{array}$ & $\begin{array}{c}2.41 \\
(0.83) \\
\end{array}$ & $\begin{array}{c}3.27 \\
(0.52) \\
\end{array}$ & $\begin{array}{c}3.25 \\
(0.58) \\
\end{array}$ & $\begin{array}{c}2.80 \\
(0.64) \\
\end{array}$ & $\begin{array}{c}2.65 \\
(0.86) \\
\end{array}$ & $\begin{array}{c}2.85 \\
(0.61) \\
\end{array}$ & $\begin{array}{c}2.62 \\
(0.47) \\
\end{array}$ \\
\hline Attitudes & $\begin{array}{c}3.33 \\
(0.36)\end{array}$ & $\begin{array}{c}2.49 \\
(0.61)\end{array}$ & $\begin{array}{c}3.58 \\
(0.32)\end{array}$ & $\begin{array}{c}2.78 \\
(0.67)\end{array}$ & $\begin{array}{c}3.28 \\
(0.44)\end{array}$ & $\begin{array}{c}2.46 \\
(0.69)\end{array}$ & $\begin{array}{c}3.30 \\
(0.42)\end{array}$ & $\begin{array}{c}2.44 \\
(0.47)\end{array}$ \\
\hline
\end{tabular}

As shown in Table 2, change was significant in the experimental group and was not significant in the control group. The interaction of group by time and by ethnicity was not significant $(\mathrm{F}(3,261)=1.17$, $\mathrm{p}=.323, \eta 2=.013)$, thus revealing that the extent of change was not due to ethnic affiliation, but to group affiliation (pre/post). In other words, the extent of change was similar for both Jewish and Arab students and the initial difference was retained. As can be observed in Table 3, knowledge increased among Jewish students in the experimental group from about 67 points to about 82 points on average, and among Arab students from about 40 points to about 63 points. It stayed at about 62 points among Jewish students in the control group, and changed slightly from 53 to 59 among Arab students in the control group.

Self-efficacy increased among Jewish students in the experimental group from a mean of about 3.0 to a mean of about 3.3 (range 1-4), and among Arab students in the experimental group from a mean of about 2.4 to a mean of 3.2 (range 1-4). It stayed at about 2.8 among Jewish students in the control group, and at about 2.6 among Arab students in the control group.

Progressive attitudes increased among Jewish students in the experimental group from a mean of about 3.3 to a mean of about 3.6 (range 1-4), and among Arab students in the experimental group from a mean of about 2.5 to a mean of 2.8 (range 1-4). They stayed at about 3.3 among Jewish students in the control group, and at about 2.4 among Arab students in the control group.

Thus, the overall MANOVA analysis was significant by ethnicity $(\mathrm{F}(3,261)=54.14, \mathrm{p}<.001, \eta 2$ $=.384$ ), but, as mentioned above, not significant for the interaction of group by time and by ethnicity. It was significant for group, time, and group by time, as shown in Table 2. 


\subsection{Differences in the Three Research Variables by Level of Religiosity}

Differences were examined in the three variables in relation to the respondents' level of religiosity (secular, traditional and religious). Due to the small number of religious respondents $(\mathrm{n}=6)$ they were combined with the traditional respondents, and the entire group is referred to henceforth as "traditional".

Table 4 presents the means and SD for the research variables by group (experimental/control), by time (pre/post), and by level of declared religiosity (traditional/secular). Means in Table 4 show that secular students had more progressive attitudes $(\mathrm{F}(1,121)=5.48, \mathrm{p}=.021, \eta 2=.043)$, than traditional students, at the beginning of the study. At the beginning of the research ("pre") no differences were found in knowledge or in self-efficacy by religiosity. As shown in Table 2, change was significant in the experimental group and was not significant in the control group. The interaction of group by time and by religiosity was not significant $(\mathrm{F}(3,245)=0.97, \mathrm{p}=.406, \eta 2=.012)$, thus revealing that the extent of change was similar for both secular and traditional students, and that the initial difference in attitudes was retained. As can be observed in Table 4, progressive attitudes increased among secular students in the experimental group from a mean of about 3.1 to a mean of about 3.4 (range 1-4), and among traditional students in the experimental group from a mean of about 3.0 to a mean of 3.2 (range 1-4). They stayed at about 3.4 among secular students in the control group, and at about 3.0 among traditional students in the control group.

Thus, the overall MANOVA analysis was significant by religiosity $(\mathrm{F}(3,245)=7.85, \mathrm{p}<.001, \eta 2$ $=.088)$, but, as mentioned above, not significant for the interaction of group by time and by religiosity. It was significant for group, time, and group by time, as shown in Table 2.

Table 4. Means and standard deviations of the study variables by group, time and religiosity $(\mathrm{N}=258)$

\begin{tabular}{|c|c|c|c|c|c|c|c|c|}
\hline & \multicolumn{4}{|c|}{ Experiment } & \multicolumn{4}{|c|}{ Control } \\
\hline & \multicolumn{2}{|c|}{$\begin{array}{c}\text { Pre } \\
\text { M } \\
(\mathrm{SD}) \\
(\mathrm{n}=64) \\
\end{array}$} & \multicolumn{2}{|c|}{$\begin{array}{c}\text { Post } \\
\mathrm{M} \\
(\mathrm{SD}) \\
(\mathrm{n}=62) \\
\end{array}$} & \multicolumn{2}{|c|}{$\begin{array}{c}\text { Pre } \\
\mathrm{M} \\
(\mathrm{SD}) \\
(\mathrm{n}=62) \\
\end{array}$} & \multicolumn{2}{|c|}{$\begin{array}{c}\text { Post } \\
\text { M } \\
(\mathrm{SD}) \\
(\mathrm{n}=70) \\
\end{array}$} \\
\hline & $\begin{array}{c}\text { Tradition } \\
\text { al } \\
(\mathrm{n}=32) \\
\end{array}$ & $\begin{array}{l}\text { Secular } \\
(\mathrm{n}=32)\end{array}$ & $\begin{array}{c}\text { Tradition } \\
\text { al } \\
(\mathrm{n}=26) \\
\end{array}$ & $\begin{array}{r}\text { Secular } \\
(\mathrm{n}=36)\end{array}$ & $\begin{array}{c}\text { Tradition } \\
\text { al } \\
(\mathrm{n}=25)\end{array}$ & $\begin{array}{l}\text { Secular } \\
(\mathrm{n}=37)\end{array}$ & $\begin{array}{c}\text { Tradition } \\
\text { al } \\
(\mathrm{n}=33)\end{array}$ & $\begin{array}{r}\text { Secular } \\
(\mathrm{n}=37)\end{array}$ \\
\hline Knowledge & $\begin{array}{r}59.19 \\
(18.92) \\
\end{array}$ & $\begin{array}{c}59.86 \\
(24.01) \\
\end{array}$ & $\begin{array}{c}76.69 \\
(18.06) \\
\end{array}$ & $\begin{array}{c}77.08 \\
(18.19) \\
\end{array}$ & $\begin{array}{c}60.86 \\
(14.32) \\
\end{array}$ & $\begin{array}{c}64.68 \\
(20.41) \\
\end{array}$ & $\begin{array}{c}55.65 \\
(25.12) \\
\end{array}$ & $\begin{array}{c}67.29 \\
(21.20) \\
\end{array}$ \\
\hline Self-efficacy & $\begin{array}{c}2.90 \\
(0.86) \\
\end{array}$ & $\begin{array}{c}2.68 \\
(0.65) \\
\end{array}$ & $\begin{array}{c}3.21 \\
(0.56) \\
\end{array}$ & $\begin{array}{c}3.30 \\
(0.51) \\
\end{array}$ & $\begin{array}{c}2.77 \\
(0.66) \\
\end{array}$ & $\begin{array}{c}2.77 \\
(0.70) \\
\end{array}$ & $\begin{array}{c}2.78 \\
(0.57) \\
\end{array}$ & $\begin{array}{c}2.79 \\
(0.66) \\
\end{array}$ \\
\hline Attitudes & $\begin{array}{c}3.03 \\
(0.62)\end{array}$ & $\begin{array}{c}3.10 \\
(0.60)\end{array}$ & $\begin{array}{c}3.24 \\
(0.70)\end{array}$ & $\begin{array}{c}3.45 \\
(0.43)\end{array}$ & $\begin{array}{c}2.97 \\
(0.57)\end{array}$ & $\begin{array}{c}3.36 \\
(0.35)\end{array}$ & $\begin{array}{c}2.91 \\
(0.55)\end{array}$ & $\begin{array}{c}3.36 \\
(0.45)\end{array}$ \\
\hline
\end{tabular}

\subsection{Differences between Control and Experimental Groups in Self-Efficacy and Extent of Progressiveness in Attitudes, According to Completion of Sentences}

Differences were examined between the control and experimental groups with regard to the respondents' self-efficacy and extent of progressiveness in their attitudes, based on an analysis of the completion of four incomplete sentences, for which high к values were obtained (see section entitled "Research tools").

The first sentence, after completion, was encoded in order to reflect a high perception of self-efficacy (1) or a low perception of self-efficacy (0). The next three sentences, after completion, were encoded to reflect progressive attitudes (1) or conservative attitudes (0). Table 5 presents the distribution of the sentences, relating to self-efficacy and progressiveness, by group and time. 
Table 5. Distribution of progressive attitudes by group and time

\begin{tabular}{|c|c|c|c|c|c|c|}
\hline & \multicolumn{3}{|c|}{ Experiment } & \multicolumn{3}{|c|}{ Control } \\
\hline & $\begin{array}{l}\text { Pre } \\
\mathrm{N} \\
(\%) \\
(\mathrm{n})\end{array}$ & $\begin{array}{l}\text { Post } \\
\text { N } \\
(\%) \\
(\mathrm{n})\end{array}$ & $\begin{array}{c}\text { Change } \\
\text { Z }\end{array}$ & $\begin{array}{l}\text { Pre } \\
\mathrm{N} \\
(\%) \\
(\mathrm{n}) \\
\end{array}$ & $\begin{array}{l}\text { Post } \\
\mathrm{N} \\
(\%) \\
(\mathrm{n}) \\
\end{array}$ & $\begin{array}{c}\text { Change } \\
\text { Z }\end{array}$ \\
\hline $\begin{array}{l}\text { If I am asked to teach a } \\
\text { lesson on sex education to } \\
\text { my pupils, I... }\end{array}$ & $\begin{array}{c}49 \\
(69.0) \\
(\mathrm{n}=71)\end{array}$ & $\begin{array}{c}47 \\
(79.7) \\
(\mathrm{n}=59)\end{array}$ & 1.38 & $\begin{array}{c}51 \\
(76.1) \\
(\mathrm{n}=67)\end{array}$ & $\begin{array}{c}40 \\
(61.5) \\
(\mathrm{n}=65)\end{array}$ & -1.81 \\
\hline $\begin{array}{l}\text { If my son tells me, that he } \\
\text { is a homosexual, I... }\end{array}$ & $\begin{array}{c}44 \\
(65.7) \\
(\mathrm{n}=67) \\
\end{array}$ & $\begin{array}{c}44 \\
(75.9) \\
(\mathrm{n}=58) \\
\end{array}$ & 1.25 & $\begin{array}{c}58 \\
(79.4) \\
(\mathrm{n}=73) \\
\end{array}$ & $\begin{array}{c}48 \\
(80.0) \\
(n=60) \\
\end{array}$ & 0.08 \\
\hline $\begin{array}{l}\text { If I discover, that my } \\
\text { female friend is having } \\
\text { oral sex, I.... }\end{array}$ & $\begin{array}{c}49 \\
(79.0) \\
(\mathrm{n}=62) \\
\end{array}$ & $\begin{array}{c}47 \\
(90.4) \\
(\mathrm{n}=52) \\
\end{array}$ & 1.66 & $\begin{array}{c}54 \\
(88.5) \\
(\mathrm{n}=61) \\
\end{array}$ & $\begin{array}{c}49 \\
(80.3) \\
(\mathrm{n}=61)\end{array}$ & -1.25 \\
\hline $\begin{array}{l}\text { If I find out that my four- } \\
\text { year-old son is } \\
\text { masturbating, I.... }\end{array}$ & $\begin{array}{c}28 \\
(43.1) \\
(\mathrm{n}=65)\end{array}$ & $\begin{array}{c}36 \\
(69.2) \\
(\mathrm{n}=52)\end{array}$ & $2.82^{* *}$ & $\begin{array}{c}33 \\
(55.0) \\
(\mathrm{n}=60)\end{array}$ & $\begin{array}{c}32 \\
(53.3) \\
(\mathrm{n}=60)\end{array}$ & -0.18 \\
\hline
\end{tabular}

$* \mathrm{p}<.05, * * \mathrm{p}<.01$

Table 5 presents the percent of progressive attitudes, as reflected by progressive sentence completion, by group and time, as well as the significance of time differences within each group. Results in the table do not show an increase in progressive completion of sentences in the experimental group, except in the last sentence ("If I find out that my four year old son is masturbating, I....").

In order to examine the validity of the sentences, several correlations were examined by means of convergent validity testing. A positive correlation was found between self-efficacy, as emerged from rated items on a Likert scale, and the way in which the first sentence was completed ("If I am asked to teach a lesson on sex education to my pupils, I..."): $\mathrm{r}=0.37(\mathrm{p}<.001)$, beyond group and time.

A positive correlation was found between the extent of progressiveness in attitudes, as revealed from rated items on a Likert scale, and the way in which the following three sentences $(2,3$ and 4$)$ were completed in: $\mathrm{r}=0.53, \mathrm{r}=0.56$ and $\mathrm{r}=0.36(\mathrm{p}<.001)$ respectively.

\section{Discussion}

This research examined differences between Jewish and Arab student teachers in an Israeli multicultural college, who participated in a "Human Sexuality" course, and those who did not. Differences were examined with regard to three variables: knowledge, attitudes concerning different aspects of human sexuality and self-efficacy to deal with sex education. It also examined correlations between each of these variables and the student's ethnic affiliation and extent of religiosity.

The main findings indicate a significant increase in knowledge and self-efficacy to deal with sex education in the experimental group at the end of the course in both ethnic groups. No significant changes were observed in the control group. Attitudes towards different issues of human sexuality were more progressive at the end of the course in the experimental group, but did not change in the control group. Research hypotheses, which predicted there would be an improvement in the three research variables at the end of the course (in the experimental group), were confirmed.

The teacher students in the experimental group demonstrated attitudes towards human sexuality that were more progressive at the end of the course, than at its beginning. This finding is in line with previous research results $[8,9,4,7,5]$, indicating that providing knowledge on sexuality contributes to constructing progressive attitudes and tolerance concerning issues of sexuality. An improvement in the self-efficacy of teachers to teach after acquisition of knowledge in the relevant subject matter, in this case-sex education, was also documented in the professional literature [25]. These scholars have advocated that teacher training should focus on the development of content knowledge, since it will have implications for the teacher's confidence to teach. Similar findings indicate a correlation between 
Iranian teachers' knowledge of English at the inception of their professional career, and their self-efficacy to teach the language [26].

According to the second research hypothesis, it was predicted that ethnic affiliation would be related with differences in knowledge, differences in attitudes toward sexuality and sex education and differences in self-efficacy regarding teaching about sexuality.

This hypothesis was confirmed. It was found that the Jewish students demonstrated more knowledge and more progressive attitudes towards issues of human sexuality and a higher self-efficacy than Arab students did, both before and after the course. Nevertheless, these differences should be considered with caution due to the small number of Arab respondents. It is noted that at the beginning of the research, as at its end, the differences between the ethnic groups were maintained: knowledge and self-efficacy were higher among Jewish students in comparison to Arab students, and Jewish students also held more progressive attitudes towards issues of sexuality. The extent of change was identical in the experimental group for both ethnic groups, meaning that the initial differences between them were sustained. Surprisingly, the extent of change in the two ethnic groups was identical; the researchers expected that the extent of the change would be less in the Arab group, as they are a more conservative ethnic group. No change was observed in the control group in either ethnic group.

The differences in knowledge, attitudes and self-efficacy to deal with sex education between the two ethnic groups can be attributed to cultural differences between Jewish and Arab societies in Israel. Arab society in Israel is largely more conservative [35]. Abu-Baker et al. [32] also pointed out more conservative attitudes among Arab teachers in Israel, in comparison to Jewish teachers. These findings are compatible with the arguments of Kukulu et al. [6], that attitudes toward sexuality are determined primarily by cultural traditions and societal norms.

According to the second research hypothesis, it was predicted that religiosity will be related with differences in knowledge, differences in attitudes toward sexuality and sex education, and differences in self-efficacy regarding teaching about sexuality.

It appears from the present findings, that secular students already held more progressive attitudes than traditional students did at the beginning of the research. This difference was maintained irrespective of group (control/experimental). The extent of change in attitude was identical both among secular and traditional students in the experimental group. This means that the initial difference between secular and traditional students was sustained. However, no difference was found in self-efficacy and knowledge between secular and traditional students. Among those who did not complete the "Human Sexuality" course, no change was visible in the three research variables. The relation found in this study between level of religiosity and extent of progressiveness in attitudes towards sexuality, is similar to that found in other studies in Israel [13] and in other countries $[18,36,37,12,14,38]$. These studies found that people who defined themselves as secular possessed more progressive attitudes than people who defined themselves as traditional or religious.

The findings of the present study indicate its importance: it seems that the acquisition of knowledge on issues of human sexuality relates to the adoption of attitudes that are more progressive and to a higher self-efficacy to deal with sex education. These findings are valid for both Jewish and Arab student teachers, and for both secular and traditional student teachers. In other words, a course dealing with different aspects of human sexuality, and particularly with sex education, contributes to the formation of more progressive attitudes towards sexuality among a diverse population. This is important especially when the course participants are student teachers, who will in the future be in a position to teach and educate children and adolescents, even if not specifically sex education. Teachers with progressive attitudes tend to promote tolerant considerations of diversity, for example towards students with unisexual tendencies. Such teachers, therefore, tend to inculcate more tolerant attitudes in their students.

A report by UNESCO [20] notes that effective sex education can empower young people to adopt responsible healthy behavior, and to avoid sexually transmitted diseases, unwanted pregnancies and harmful sexual activities. Similarly, Harpaz [1] argues that part of the purpose of sex education is to counter the negative perception of sex, which children are exposed to and absorb from television and the internet. It is important to teach young people to respect and enjoy their sexual urges, and at the same time, to give them the tools so they know how to control their sexual urges in a responsible and healthy manner. 
The main limitation of this research is using a between-subjects design, rather than a within subjects design. This precluded the possibility to use repeated measures statistics. An additional limitation has to do with the low validity of the questionnaire. Although it underwent evaluation by three judges with expertise in the relevant fields to clarify and examine its composition, it did not undergo standard validation procedures, with regard to its construct validity, criterion validity, and discriminant validity.

Follow-up research should be considered in the form of a longitudinal study to investigate the degree to which graduates of the college's "Human Sexuality" course have put their improved knowledge, changed attitudes, and enhanced perception of self-efficacy, into practice in their work as teachers. Such research could shed light on the long-term implications of the course on the personal and professional levels. Additionally, a qualitative follow-up research is recommended, in which student teachers are encouraged to express their thoughts, feelings, and beliefs with regard to the subject of human sexuality and sex education. Such research into the student teachers' subjective perceptions would give further insight into the short and long-term effects of completing a human sexuality course as part of their teaching training.

\section{References}

1. Y. Harpaz (2010b), "Loss of education is also loss of sex education". Hed Hahinuch, vol. 84, no. 6, pp. 38-41 (in Hebrew).

2. A. Zvieli-Efrat (2010). Secrets and fears - being LGBT in school. Hed Hahinuch, vol. 84, no. 6, pp. 82-84 (in Hebrew).

3. D. Harrari (2010), "We will always think they are too young". Hed Hahinuch, vol. 84, no. 6, pp. 58-60 (in Hebrew).

4. C. M. Meston, P. D. Trapnell and B. B. Gorzalka (1998), "Ethnic, gender and length of residency influences on sexual knowledge and attitudes". The Journal of Sex Research, vol. 35, no. 2, pp. 176-188.

5. C. M. Walcott, T. Chenneville and S. Tarquini (2011), "Relationship between recall of sex education and college students' sexual attitudes and behavior". Psychology in the Schools, vol. 48, no. 8, pp. 828-842.

6. K. Kukulu, E. Gursoy and G. A. Sozer (2009), "Turkish university students' beliefs in sex myths". Sex Disability, vol. 27 , pp. 49-59.

7. R. M. Noland, M. A. Bass, R. S. Keathley and R. Miller (2009), "Is a little knowledge a good thing? College students gain knowledge, but knowledge increase does not equal attitude change regarding same-sex sexual orientation and gender reassignment surgery in sexuality courses". American Journal of Sexuality Education, vol. 4, no. 2, pp. 139-157.

8. A. Ben Ari (1998), "An experiential attitude change: Social work students and homosexuality". Journal of Homosexuality, vol. 36, no. 2, pp. 59-71.

9. H. Cao, P. Wang and Y. Gao (2010), "A survey of Chinese university students' perceptions of and attitudes towards homosexuality". Social Behavior and Personality, vo. 38, no. 6, pp. 721-728.

10.N. Sakalli-Ugurlu (2001), "Effects of social contact with homosexuals on heterosexual Turkish university students' attitudes towards homosexuality". Journal of Homosexuality, vol. 42, no. 1, pp. 53-62.

11.D. W. Riggs, K. Webber and G. R. Fell (2012), "Australian undergraduate psychology students' attitudes towards trans people". Gay and Lesbian Issues and Psychology Review, vol. 8, no. 1, pp. 52-64.

12.C. Perez-Testor, J. Behar, M. Davins, J. L. Conde-Sala, J. A. Castillo, M. Salamero, E. Alomar and S. Segarra (2010), "Teachers' attitudes and beliefs about homosexuality". The Spanish Journal of Psychology, vol.13, no. 1, pp. $138-155$.

13.G. Shilo (2009),"Social work students' attitudes towards homosexuality". Hevra veRevacha, vol. 29, no. 4, pp. 455-481 (in Hebrew).

14.Z. H. Sumer (2014), Gender, religiosity, sexual activity, sexual knowledge, and attitudes toward controversial aspects of sexuality. Available http://link.springer.com/article/10.1007\%2Fs10943-014-9831-5

15.A. Ayalon (2006), Attitudes towards sex and sexuality. Available: http://www.midgam.com/article.asp?ArticleId=12 (in Hebrew).

16.R. O. De Visser, A. M. A. Smith, J. Richters and C. E. Rissel (2007), "Associations between religiosity and sexuality in a representative sample of Australian adults". Archives of Sexual Behavior, vol. 36, pp. 33-46. 
17.B. E. Whitley, C. E. Childs and J. B. Collins (2011), "Differences in black and white American college students' attitudes toward lesbians and gay men". Sex Roles, vol. 64, no. 5, pp. 299-310.

18.K. T. Ahrold and C. M. Meston (2010), "Ethnic differences in sexual attitudes of U.S. college students: Gender, acculturation and religiosity factors", Arch Sex Behavior, vol. 39, pp. 190-202.

19.B. M. King (2012), "The need for school-based comprehensive sexuality education: Some reflections after 32 years teaching sexuality to college students". American Journal of Sexuality Education, vol. 7, no. 3, pp. 181-186.

20.UNESCO, (2009), International technical guidance on sexuality education. Available: http://unesdoc.unesco.org/images/0018/001832/183281e.pdf

21.Y. Harpaz (2010a), "A sex dilemma". Hed Hahinuch, vol. 84, no. 6, pp. 6 (in Hebrew).

22.J. Corngold (2013), "Introduction: The ethics of sex education". Educational Theory, vol. 63, no. 5, pp. 439-442.

23.J. M. Chonody, S. F. Rutledge and D. C. Siebert (2009), "College students' attitudes towards gays and lesbians". Journal of Social Work Education, vol. 45, no. 3, pp. 499-512.

24.R. Ingham and S. Mayhew (2006), "Research and policy in sexual health", in Promoting Young People's Sexual Health: International Perspectives. Routledge, pp. 209-225.

25.E. Rohaan, R. Taconis and W. Jochems (2012), "Analysing teacher knowledge for technology education in primary schools". International Journal of Technology and Design Education, vol. 22, no. 3, pp. 271-280.

26.A. Zakeri and M. Alavi (2011), "English language teachers' knowledge and their self-efficacy". Journal of Language Teaching and Research, vol. 2, no. 2, pp. 413-419.

27.T. J. Wyatt (2009), "Pre service educators' confidence in addressing sexuality education". Teacher Education and Practice, vol. 22, no. 1, pp. 43-63.

28.WHO-World Health Organization (2002), The world health report reducing risks, promoting healthy life. Available: http://www.who.int/whr/2002/en/

29.P. Iyer and P. Aggleton (2013), "Sex education should be taught, fine... but we make sure they control themselves: Teachers' beliefs and attitudes towards young people's sexual and reproductive health in a Ugandan secondary school". Sex Education, vol. 13, no. 1, pp. 40-53.

30.I. Gursimsek (2010), "Sexual education and teacher candidates' attitudes towards sexuality". Australian Journal of Guidance and Counselling, vol. 20, no. 1, pp. 81-90.

31.L. Rojas-Guyler and K. A. King (2007), "Sexuality education among Latinas: Experiences, preferences, attitudes and risk behavior". American Journal of Sexuality Education, vol. 2, no. 4, pp. 25-41.

32.K. Abu-Baker, A. Rekhal and A. Biadse-Ashkar (2012), "Teachers' and parents' attitudes towards sex education: Age and culture differences", paper presented at the 8th research conference at Academic College of Emek Yezreel, Israel (in Hebrew).

33.A. Weissblei (2010), Sex education in the education system. Jerusalem: The Knesset, Research and Information Centre. Available: http://www.knesset.gov.il/mmm/data/pdf/m02462.pdf (in Hebrew).

34.M. E. Kite and K. Deaux (1986), "Attitudes toward homosexuality: Assessment and behavioral consequences". Basic and Applied Social Psychology, vol. 7, pp. 137-162.

35.A. Zahalkah (2007). From traditionalism to openness, intra-cultural. Hevra veHinuch, 38. (in Hebrew). Available: http://www.itu.org.il/?CategoryID=1150\&ArticleID=8881

36.J. K. Davidson, N. B. Moore and K. M. Ullstrup, K. M. (2004), "Religiosity and sexual responsibility: Relationships of choice". American Journal of Health Behavior, vol. 28, no. 4, pp. 335-346.

37.L. Edwards, R. Fehring, K. M. Jarrett and K. Haglund (2008), "The influence of religiosity, gender and language preference acculturation on sexual activity among Latino-American adolescents". Hispanic Journal of Behavioral Sciences, vol. 30, no. 4, pp. 447-462.

38.C. H. Zaleski and K. M. Schiaffino (2000), "Religiosity and sexual risk-taking behavior during the transition to college". Journal of Adolescence, vol. 23, no. 2, pp. 223-227. 